\title{
PENGARUH FAKTOR MAKROEKONOMI, DANA PIHAK KETIGA DAN PANGSA PEMBIAYAAN TERHADAP PROFITABILITAS INDUSTRI PERBANKAN SYARIAH DI INDONESIA TAHUN 2011-20151)
}

\author{
Laras Andasari Syachfuddin \\ Mahasiswa Program Studi SI Ekonomi Islam - Fakultas Ekonomi dan Bisnis - Universitas \\ Airlangga \\ Email: laras.andasari-12@feb.unair.ac.id \\ Suherman Rosyidi \\ Departemen Ekonomi Syariah - Fakultas Ekonomi dan Bisnis - Universitas Airlangga \\ Email: srosyidi@gmail.com
}

\begin{abstract}
:
This study aims to determine the effect of macroeconomics factor, third party funds and market share to profitability sharia banks industry period 2011 until 2015. The research method used is a quantitative approach. The dependent variable in this study is profitability (ROA), as well as the independent variable in this study is macroeconomics factor (inflation and gross domestic product), third party funds and market share. Sampling method in this research used a saturated sampling. The analysis technique used is multiple linier regression.

Research result shows that the confidence level is 95\%, macroeconomics factor (inflation and gross domestic product) and third party funds have a negative correlation to profitability (ROA). Simultaneously variables in this study a significant effect on the magnitude of the amount of profitability (ROA) sharia banks industry with $84.4 \%$ value of coefficient determination. The partially, third party funds and market share had significant effect to profitability (ROA) sharia banks industry.
\end{abstract}

Keywords: Macroeconomics Factor, Third Party Funds, Market Share, Profitability

\section{PENDAHULUAN}

\section{Latar Belakang}

Bank memiliki peranan penting dalam perekonomian yang berperan sebagai penghimpun dan penyalur dana masyarakat. "Bank juga bertujuan menunjang pelaksanaan pembangunan nasional dalam rangka meningkatkan pemerataan, pertumbuhan ekonomi, dan stabilitas nasional ke arah peningkatan rakyat banyak" (Hasibuan, 2001:4).

Di Indonesia terdapat dua sistem perbankan yang digunakan, yaitu bank syariah dan bank konvensional. Pada bank syariah tidak mengenal adanya bunga di dalam operasinya. Dengan demikian, bank syariah tidak mendapatkan penghasilan dari bunga

atau riba. Salah satu bentuk penghasilan bank syariah adalah "bagi hasil dengan pelaku usaha yang menggunakan dana dari bank syariah serta investasi dari bank syariah sendiri" (Antonio, 2001:18).

Di Indonesia perbankan syariah terbagi menjadi beberapa jenis, yaitu Bank Umum Syariah (BUS), Unit Usaha Syariah (UUS), dan Bank Pembiayaan Rakyat Syariah (BPRS). Sebagai lembaga yang penting dalam perekonomian, bank memerlukan adanya pengawasan kinerja yang baik oleh regulator perbankan. "Salah satu indikator untuk menilai kinerja keuangan suatu bank adalah melihat tingkat profitabilitasnya" (Hasibuan, 2001:100).

\footnotetext{
1) Jurnal ini adalah bagian dari skripsi Laras Andasari Syachfuddin NIM.041211433045 yang diuji pada 31 Januari 2017
} 
Syachfuddin, et al/Jurnal Ekonomi Syariah Teori dan Terapan Vol. 4 No. 12 Desember 2017: 977-993; PENGARUH FAKTOR MAKROEKONOMI, DANA PIHAK KETIGA DAN PANGSA PEMBIAYAAN TERHADAP PROFITABILITAS INDUSTRI PERBANKAN SYARIAH DI INDONESIA TAHUN 2011-2015

Salah satu indikator yang digunakan untuk mengukur tingkat profitabilitas adalah return on assets (ROA).

Dalam pelaksanaan kegiatan operasionalnya, bank tidak terlepas dari pengaruh kondisi perekonomian. Sukirno (2006:26) menyatakan bahwa, "faktorfaktor ekonomi makro seperti neraca pembayaran, pendapatan nasional meliputi produk domestik bruto dan produk nasional bruto, tingkat pertumbuhan ekonomi, tingkat inflasi, tingkat pengangguran, nilai tukar valas, jumlah uang beredar, dan suku bunga".

Secara teoritik, bank syariah merupakan bank independen yang terpisah dari sistem bunga yang berlaku pada bank konvensional pada umumnya. Meski demikian, keberadaan bunga dapat pula memiliki pengaruh terhadap kinerja bank syariah. Hal ini disebabkan apabila suku bunga naik, besar sekali kemungkinan nasabah bank syariah, baik aktual maupun potensial berpindah dari bank syariah ke bank konvensional; dan ini berarti perubahan suku bunga mempengaruhi bank syariah. Bukti lain dari kenyataan ini adalah bahwa kondisi eksternal berpengaruh terhadap ROA seperti yang ditunjukkan pada Tabel 1 berikut:
Tabel 1

Perkembangan Tahunan Inflasi, Gross Domestic Product (GDP), Dana Pihak Ketiga (DPK), Pangsa Pasar, dan ROA

\begin{tabular}{|c|c|c|c|c|c|}
\hline Tahun & 2011 & 2012 & 2013 & 2014 & 2015 \\
\hline $\begin{array}{l}\text { Inflasi } \\
(\%)\end{array}$ & 3,79 & 4,30 & 8,38 & 8,36 & 3,35 \\
\hline $\begin{array}{l}\text { GDP } \\
\text { (triliun } \\
\text { rupiah) }\end{array}$ & 2.465 & 2.619 & 2.769 & 2.909 & 3.256 \\
\hline $\begin{array}{l}\text { DPK } \\
\text { (miliar } \\
\text { rupiah) }\end{array}$ & $\begin{array}{l}115.4 \\
17 \\
\end{array}$ & $\begin{array}{l}147.5 \\
15\end{array}$ & $\begin{array}{l}183.5 \\
38\end{array}$ & $\begin{array}{l}217.8 \\
62 \\
\end{array}$ & $\begin{array}{l}231.1 \\
80\end{array}$ \\
\hline $\begin{array}{l}\text { Pangsa } \\
\text { Pasar } \\
(\%)\end{array}$ & 2,88 & 3,36 & 3,62 & 3,46 & 3,39 \\
\hline $\begin{array}{l}\text { ROA } \\
\text { (\%) }\end{array}$ & 4,46 & 4,78 & 4,79 & 4,64 & 4,50 \\
\hline
\end{tabular}

Periode 2011-2015

Sumber: Statistik Perbankan Syariah dan Laporan Perekonomian Indonesia 20112015

Tabel 1 menjelaskan bahwa inflasi, gross domestic product (GDP), dana pihak ketiga (DPK), pangsa pasar, dan ROA di Indonesia dari tahun ke tahun mengalami fluktuasi. Fluktuasi dapat dilihat dari sisi inflasi yang selalu mengalami kenaikan kecuali tahun 2015 yang mengalami disinflasi dari $8,36 \%$ menjadi $3,35 \%$. GDP dan dana pihak ketiga (DPK) selalu mengalami peningkatan setiap tahunnya. Pangsa pasar dan ROA dari tahun ke tahun mengalami peningkatan, tetapi pada tahun 2014 dan 2015 mengalami penurunan.

Selain faktor di atas, terdapat faktor lain yang berpengaruh terhadap return on asset (ROA), yaitu pangsa pasar. Pangsa pasar penelitian ini merupakan pembiayaan yang disalurkan oleh bank syariah. Gale menyatakan bahwa dampak dari pangsa pasar terhadap profitabilitas cenderung lebih besar ketika ukuran perusahaan relatif lebih besar atau 
Syachfuddin, et al/Jurnal Ekonomi Syariah Teori dan Terapan Vol. 4 No. 12 Desember 2017: 977-993; PENGARUH FAKTOR MAKROEKONOMI, DANA PIHAK KETIGA DAN PANGSA PEMBIAYAAN TERHADAP PROFITABILITAS INDUSTRI PERBANKAN SYARIAH DI INDONESIA TAHUN 2011-2015

ketika di dalam lingkungan persaingan yang dicirikan dengan konsentrasi tinggi atau pertumbuhan yang moderat (Gale, 1972:422).

Berdasarkan latar belakang yang diuraikan di atas, maka penelitian ini mengambil judul "Pengaruh Inflasi, Gross Domestic Product (GDP), Dana Pihak Ketiga (DPK), dan Pangsa Pasar terhadap Return on Asset (ROA) Industri Perbankan Syariah di Indonesia Periode 2011-2015". Yang dimaksud perbankan syariah di judul tersebut terdiri dari Bank Umum Syariah (BUS), Unit Usaha Syariah (UUS), dan Bank Pembiayaan Rakyat Syariah (BPRS) di seluruh Indonesia. Sedangkan return on assets (ROA) sebagai alat untuk mengetahui kinerja aset yang dimiliki perbankan syariah dalam memperoleh laba. Selanjutnya terdapat beberapa variabel eksternal yang mempengaruhi kinerja bank, yaitu inflasi, gross domestic product (GDP), dana pihak ketiga (DPK), dan pangsa pasar.

\section{Rumusan Masalah}

Berdasarkan uraian latar belakang di atas, maka rumusan masalah penelitian ini adalah:

1. Apakah inflasi, gross domestic product (GDP), dana pihak ketiga (DPK), dan pangsa pasar berpengaruh secara parsial terhadap return on asset (ROA) industri perbankan syariah di Indonesia?

2. Apakah inflasi, gross domestic product (GDP), dana pihak ketiga (DPK), dan pangsa pasar berpengaruh secara simultan terhadap return on asset
(ROA) industri perbankan syariah di Indonesia?

\section{Tujuan Penelitian}

1. Untuk mengetahui pengaruh inflasi, gross domestic product (GDP), dana pihak ketiga (DPK), dan pangsa pasar secara parsial terhadap return on asset (ROA) industri perbankan syariah di Indonesia.

2. Untuk mengetahui pengaruh inflasi, gross domestic product (GDP), dana pihak ketiga (DPK), dan pangsa pasar secara simultan terhadap return on asset (ROA) industri perbankan syariah di Indonesia.

\section{TINJAUAN PUSTAKA}

\section{Perbankan Syariah}

Menurut Undang-Undang Nomor 21 Tahun 2008 tentang Perbankan Syariah dalam pasal 1 ayat 7 menyatakan bahwa "Bank Syariah adalah Bank yang menjalankan kegiatan usahanya berdasarkan Prinsip Syariah dan menurut jenisnya terdiri atas Bank Umum Syariah dan Bank Pembiayaan Rakyat Syariah". Perbankan syariah menjalankan kegiatannya berdasarkan dengan prinsip syariah yang telah diatur oleh fatwa-fatwa tentang perbankan.

Bank umum syariah merupakan salah satu jenis bank syariah yang menjalankan kegiatan perbankan dengan menggunakan prinsip syariah. Menurut Undang-Undang Nomor 21 Tahun 2008 tentang Perbankan Syariah dalam pasal 1 ayat 8 "Bank umum syariah adalah bank syariah yang dalam kegiatannya memberi jasa dalam lalu 
Syachfuddin, et al/Jurnal Ekonomi Syariah Teori dan Terapan Vol. 4 No. 12 Desember 2017: 977-993; PENGARUH FAKTOR MAKROEKONOMI, DANA PIHAK KETIGA DAN PANGSA PEMBIAYAAN TERHADAP PROFITABILITAS INDUSTRI PERBANKAN SYARIAH DI INDONESIA TAHUN 2011-2015

lintas pembayaran". Terdapat beberapa bank syariah yang termasuk dalam bank umum syariah, misalnya saja salah satu pelopor bank syariah di Indonesia yaitu Bank Muamalat Indonesia.

Menurut Undang-Undang Nomor 21 Tahun 2008 tentang Perbankan Syariah, "Unit usaha syariah memiliki transaksi yang terpisah dari bank konvensional karena semua transaksi syariah tidak boleh tercampur dengan transaksi konvensional.Unit usaha syariah dapat melaksanakan fungsi sosial sesuai dengan peraturan perundang-undangan".

Menurut PBI No. 11/23/PBI/2009, "Keberadaan BPRS dimaksudkan untuk dapat memberikan layanan perbankan secara cepat, mudah, dan sederhana kepada masyarakat khususnya pengusaha menengah, kecil dan mikro, baik di pedesaan maupun perkotaan yang selama ini belum terjangkau oleh layanan bank umum". BPRS sebagai salah satu lembaga keuangan syariah yang kegiatan usahanya berdasarkan prinsip syariah, harus dapat menjalankan amanah dari para pemilik dana dengan cara menyalurkannya untuk usaha produktif dalam rangka meningkatkan taraf hidup masyarakat.

\section{Return on Asset}

Pendapat Jones

mengenai ROA adalah "a fundamental measure of firm profitability, reflecting how effectively and efficiently the firm's assets are used. Obviously the higher the net income for a given amount of assets, the better the return". Menurut Surat Edaran BI
No.3/30DPNP tanggal 14 Desember 2001, ROA dapat dihitung dengan perbandingan antara laba sebelum pajak dan assets total (total aktiva). Formula return on asset (ROA) yang digunakan dalam Surat Edaran BI tersebut di atas adalah :

$\mathrm{ROA}=\frac{\text { Laba sebelum pajak }}{\text { Total aset }}$

Inflasi

Mengenai teori inflasi konvensional, Karim (2010:135) menyatakan bahwa "secara umum inflasi berarti kenaikan tingkat harga secara umum dari barang/komoditas dan jasa selama suatu periode waktu tertentu. Inflasi dapat dianggap sebagai fenomena moneter karena terjadinya penurunan nilai unit perhitungan moneter terhadap suatu komoditas".

Menurut para ekonom Islam, inflasi berakibat sangat buruk bagi perekonomian, (Karim, 2010:139) karena:

1. Menimbulkan gangguan terhadap fungsi uang, terutama terhadap fungsi tabungan (nilai simpan), fungsi dari pembayaran di muka, fungsi dari unit perhitungan.

2. Melemahkan semangat menabung dan sikap terhadap menabung dari masyarakat (turunnya marginal propensity to save).

3. Mengakibatkan kecenderungan untuk berbelanja terutama untuk non-primer dan barang-barang 
Syachfuddin, et al/Jurnal Ekonomi Syariah Teori dan Terapan Vol. 4 No. 12 Desember 2017: 977-993; PENGARUH FAKTOR MAKROEKONOMI, DANA PIHAK KETIGA DAN PANGSA PEMBIAYAAN TERHADAP PROFITABILITAS INDUSTRI PERBANKAN SYARIAH DI INDONESIA TAHUN 2011-2015

mewah (naiknya marginal propensity to consume).

4. Mengarahkan investasi pada hal-hal yang non-produktif, yaitu penumpukan kekayaan (hoarding) seperti: tanah, bangunan, logam mulia, mata vang asing dengan mengorbankan investasi ke arah poduktif seperti: pertanian, industrial, perdagangan, transportasi, dan lainnya.

Rumus yang digunakan untuk mencari inflasi adalah sebagai berikut (Samuelson, 1992:400):

Rate of inflation

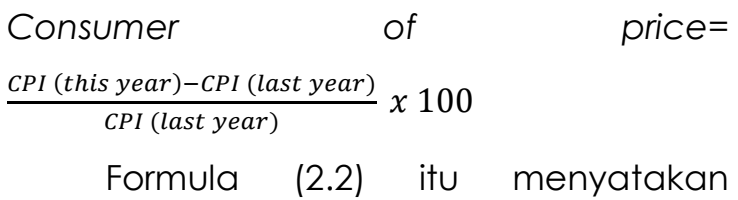
bahwa inflasi :

1. Merupakan perbandingan antara CPI saat ini dengan CPI dimasa yang lalu.

2. Inflasi dinyatakan dalam persen.

\section{Gross Domestic Product (GDP)}

Menurut Mankiw (2002:326) "gross domestic product (GDP) is the market value of all final goods and services produced within a country in a given peiod of time". GDP dapat diukur dengan tiga hal, yaitu produksi untuk menghasilkan barang dan jasa, pendapatan total semua orang, dan jumlah pengeluaran dalam perekonomian. GDP mengukur ketiganya untuk mengetahui perekonomian secara keseluruhan, jumlah produksi total sama dengan jumlah pendapatan, sama dengan jumlah pengeluaran.

Boediono (1982:11), menyatakan bahwa tujuan perhitungan GDP adalah "untuk mendapatkan gambaran tentang tingkat ekonomi yang telah dicapai dan nilai output yang diproduksi, komposisi pembelanjaan agregat, sumbangan dari berbagai sektor perekonomian, serta tingkat kemakmuran yang dicapai".

Perhitungan GDP mempunyai tiga pendekatan, yaitu:

1. Pendekatan Produksi (Value Added Approach)

\section{Pendekatan}

produksi merupakan nilai tambah yang diciptakan dalam proses produksi. Metode ini digunakan "untuk menghitung pendapatan nasional berdasarkan jumlah nilai barang dan jasa yang dihasilkan dari masing-masing sektor ekonomi pada periode tertentu" (Suparmoko, 1998:16). Nilai produksi suatu sektor menggambarkan nilai tambah yang dicapai dalam sektor tersebut.

2. Pendekatan Pendapatan (Income Approach/Earning Approach)

Pendekatan pendapatan mengarah pada penerimaan pada faktor-faktor produksi. Metode pendekatan pendapatan adalah "pendapatan nasional dari hasil penjumlahan yang diterima oleh pemilik faktor produksi dalam suatu 
Syachfuddin, et al/Jurnal Ekonomi Syariah Teori dan Terapan Vol. 4 No. 12 Desember 2017: 977-993; PENGARUH FAKTOR MAKROEKONOMI, DANA PIHAK KETIGA DAN PANGSA PEMBIAYAAN TERHADAP PROFITABILITAS INDUSTRI PERBANKAN SYARIAH DI INDONESIA TAHUN 2011-2015

negara selama satu tahun" (Suparmoko, 1998:17). Faktor-faktor produksi terdiri dari tenaga kerja, modal, tanah, dan keahlian. Faktorfaktor produksi ini akan menghasilkan pendapatan yang berbeda, yaitu tenaga kerja akan memperoleh upah/gaji, pemilik modal akan mendapatkan bunga, pemilik tanah akan memperoleh sewa, dan keahlian akan memperoleh laba.

3. Pendekatan Pengeluaran (Expenditure Approach) Pendekatan pengeluaran mengarah kepada pengeluaran sektor ekonomi pada suatu negara. Pendekatan pengeluaran dilakukan dengan "menjumlahkan seluruh pengeluaran berbagai sektor ekonomi, yaitu rumah tangga, perusahaan, pemerintah, dan sektor luar negeri (ekspor dan impor) suatu negara pada periode tertentu" (Suparmoko, 1998:20). Jenis pengeluaran dari masing-masing pelaku ekonomi, yaitu rumah tangga dalam bentuk pengeluaran konsumsi perseorangan maupun rumah tangga, perusahaan mempunyai pengeluaran investasi, pemerintah mempunyai pengeluaran dalam bentuk konsumsi pemerintah, dan sektor luar negeri berupa penerimaan ekspor dan pengeluaran impor.

\section{Uji Geometric Mean}

Penelitian ini menggunakan uji geometric mean untuk menghitung GDP. Uji ini mempunyai maksud untuk menghitung rata-rata tingkat pertumbuhan. Lind, dkk (2010:69) menyatakan pendapatnya tentang geometric mean sebagai berikut:

"the geometric mean is useful in finding the average change of percentages, ratios, indexes, or growth rates over time. It has a wide application in business and economics because we are often interested in finding the percentage change in sales, salaries, or economic figures, such as gross domestic product, which compound or build on each other".

Pernyataan Lind, dkk pun dipertegas oleh Hasan (2001:90) "Rata-rata geometrik sering digunakan dalam bisnis dan ekonomi untuk menghitung rata-rata tingkat perubahan, rata-rata tingkat pertumbuhan, atau rasio rata-rata untuk data berurutan tetap atau hampir tetap atau untuk rata-rata kenaikan dalam bentuk persentase".

Penelitian ini menggunakan rumus geometric mean (Lind, dkk, 2010:70) sebagai berikut:

GM $=\sqrt[n]{\frac{\text { Value at end of period }}{\text { value at start of period }}}-1$

\section{Dana Pihak Ketiga (DPK)}

Dana pihak ketiga adalah "dana yang berasal dari masyarakat, baik perorangan maupun badan usaha, yang diperoleh bank dengan menggunakan berbagai instrumen produk simpanan 
Syachfuddin, et al/Jurnal Ekonomi Syariah Teori dan Terapan Vol. 4 No. 12 Desember 2017: 977-993; PENGARUH FAKTOR MAKROEKONOMI, DANA PIHAK KETIGA DAN PANGSA PEMBIAYAAN TERHADAP PROFITABILITAS INDUSTRI PERBANKAN SYARIAH DI INDONESIA TAHUN 2011-2015

yang dimiliki oleh bank (Kuncoro, 2002:155).

Menurut Arifin (2009:57) berdasarkan prinsip, bank syariah dapat menarik dana pihak ketiga atau masyarakat dalam bentuk:

1. Titipan (wadi'ah) simpanan yang dijamin keamanan dan pengembaliannya (guaranteed deposit) tetapi tanpa memperoleh imbalan atau keuntungan.

2. Partipasi modal berbagi hasil dan berbagi resiko (non guaranteed account) untuk investasi umum (general investment account/ mudharabah mutlaqah) di mana bank akan membayar bagian keuntungan secara proporsional dengan porofolio yang didanai dengan modal tersebut.

3. Investasi khusus (special investment account/ mudharabah muqayyadah) di mana bank bertindak sebagai manajer investasi untuk memperoleh fee. Jadi bank tidak ikut berinvestasi sedangkan investor sepenuhnya mengambil risiko atas investasi.

\section{Pangsa Pasar}

Menurut Stanton

(1978:537)

pangsa pasar dapat diartikan sebagai "the ratio of a company's sales to the total industry sales in either an actual or potential basis". Besarnya pangsa pasar setiap saat akan berubah, perubahan ini dapat disebabkan oleh selera konsumen maupun berpindahnya minat konsumen dari suatu produk ke produk yang lain.

Analisis pangsa pasar mencerminkan kinerja pemasaran yang dikaitkan dengan posisi persaingan perusahaan dalam suatu industri. Kotler (2006:650) mengatakan bahwa ukuran pangsa pasar dapat dibedakan dalam beberapa cara, yaitu:

1. Overall market share is expresses the company's sales as a percentage of total market sales.

2. Served market share is sales as a percentage of the total sales to the market and always larger than overall market share.

Relative market share is market share in relationship to the largest competitor. A relative market share of exacyly $100 \%$ means the company is tied for the lead. A rise in relative market share means a company is gaining its leading competitor.

\section{Hubungan antar variabel}

1. Inflasi diartikan sebagai "meningkatnya harga secara terus-menerus dan mempengaruhi semua kalangan masyarakat" (Suparmoko, 1998:209). Apabila terjadi inflasi yang tinggi maka keadaan perekonomian menjadi tidak stabil. Hal ini mengartikan pembiayaan yang dilakukan oleh bank syariah tergolong pembiayaan lancar. Kondisi tersebut menyebabkan profitabilitas yang didapatkan oleh bank syariah akan meningkat akibat pembiayaan yang lancar.

2. GDP menggambarkan jumlah barang dan jasa yang dihasilkan oleh faktor produksi dalam 
Syachfuddin, et al/Jurnal Ekonomi Syariah Teori dan Terapan Vol. 4 No. 12 Desember 2017: 977-993; PENGARUH FAKTOR MAKROEKONOMI, DANA PIHAK KETIGA DAN PANGSA PEMBIAYAAN TERHADAP PROFITABILITAS INDUSTRI PERBANKAN SYARIAH DI INDONESIA TAHUN 2011-2015

setahun.

Perekonomian

mengalami pertumbuhan, apabila balas jasa yang diberikan faktor produksi lebih besar dari periode sebelumnya. Sahara (2013:152) menyimpulkan bahwa GDP berpengaruh terhadap ROA. Artinya jika GDP meningkat, maka ROA juga meningkat. Dan sebaliknya jika GDP mengalami penurunan maka ROA juga akan menurun.

3. Dana pihak ketiga (DPK) merupakan salah satu sumber dana terbesar yang diperoleh dari masyarakat. Bank dapat memanfaatkan dana dari pihak ketiga ini untuk ditempatkan pada pos-pos yang menghasilkan pendapatan bagi bank. Sumber dana pihak ketiga yaitu berupa giro, tabungan, dan deposito. Setelah bank memberikan pinjaman atau pembiayaan, tentunya ada keuntungan yang diperoleh oleh bank maupun nasabah. Keuntungan yang diperoleh dari bagi hasil ini masuk dalam kas bank, sehingga bank mendapatkan tambahan kas guna mencukupi kegiatan opersional bank.

\section{Model Analisis}

Model analisis yang digunakan dalam penelitian ini adalah analisis regresi linier berganda yang menggunakan data deret waktu atau time series. Model
4. Menurut Ariyanto (2005:101) pangsa pasar membuat perusahaan memiliki kinerja yang lebih baik yang selanjutnya berdampak pada profitabilitas. Apabila suatu perusahaan memiliki pangsa pasar yang besar, maka perusahaan tersebut akan berkuasa dan mendapatkan profitabilitas yang tinggi.

\section{Hipotesis}

Menurut Anshori dan Iswati, (2009:45), hipotesis adalah "Pernyataan hubungan antara variabel dengan variabel, yang bersifat sementara atau bersifat dugaan, atau yang masih lemah". Berdasarkan pada teori dan hasil penelitian sebelumnya, maka hipotesis dari penelitian ini adalah:

$\mathrm{H}_{0}=$ Inflasi, GDP, DPK, dan pangsa pasar secara parsial maupun simultan berpengaruh signifikan terhadap return on asset (ROA) industri perbankan syariah di Indonesia pada periode 20112015.

$\mathrm{H}_{1}=$ Inflasi, GDP, DPK, dan pangsa pasar secara parsial maupun simultan tidak berpengaruh signifikan terhadap return on asset (ROA) industri perbankan syariah di Indonesia pada periode 2011-2015.

analisis dalam penelitian ini dapat digambarkan sebagai berikut: 
Syachfuddin, et al/Jurnal Ekonomi Syariah Teori dan Terapan Vol. 4 No. 12 Desember 2017: 977-993; PENGARUH FAKTOR MAKROEKONOMI, DANA PIHAK KETIGA DAN PANGSA PEMBIAYAAN TERHADAP PROFITABILITAS INDUSTRI PERBANKAN SYARIAH DI INDONESIA TAHUN 2011-2015

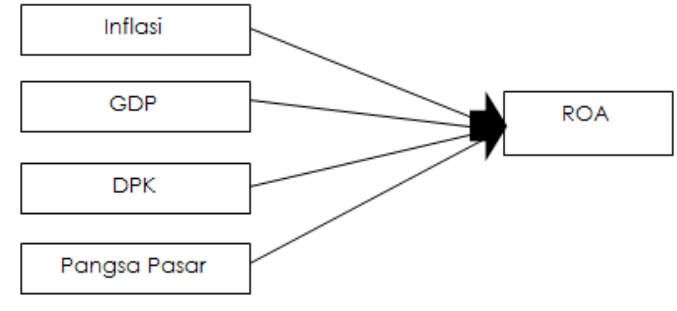

Gambar 2.1

Model Analisis Secara Parsial

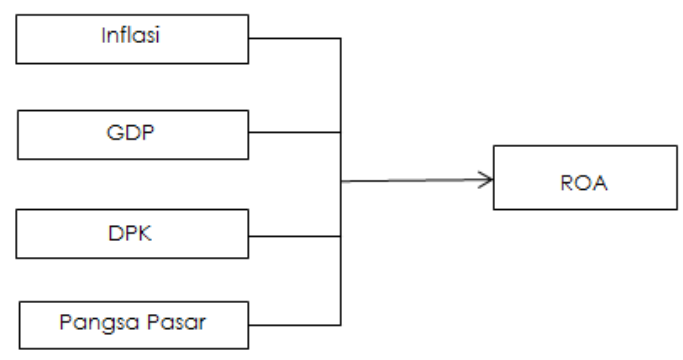

Gambar $\mathbf{2 . 2}$
Model Analisis Secara Simultan

\section{METODE PENELITIAN}

\section{Pendekatan Penelitian}

Pendekatan yang digunakan penelitian ini adalah pendekatan kuantitatif. Hal ini disebabkan penelitian ini dilakukan untuk "menguji hipotesis yang telah diajukan dan menggunakan data yang terukur serta analisis statistik. Setelah itu hasil dapat ditarik kesimpulan dan digeneralisasikan" (Sugiyono, 2012:13). Teknik analisis yang digunakan untuk mengetahui hubungan antar variable menggunakan regresi linier berganda. Adapun program statistik yang digunakan untuk mempermudah dalam pengolahan data menggunakan program SPSS versi 21.0.

\section{Identifikasi Variabel}

Variabel yang digunakan dalam penelitian ini terdiri dari dua jenis, yakni variabel independen dan variabel dependen. Variabel independen adalah variable bebas yang mempengaruhi variabel terikat atau dependen. Adapun variabel independen dalam penelitian ini adalah inflasi, gross domestic product (GDP), dana pihak ketiga (DPK), dan pangsa pasar. Variabel dependen adalah variabel terikat yang perubahannya dipengaruhi oleh variabel bebas atau independen. Adapun dalam penelitian ini variabel dependen yang digunakan adalah return on asset (ROA) industri perbankan syariah di Indonesia.

\section{Definisi Operasional Variabel}

1. Inflasi

Inflasi diartikan sebagai "meningkatnya harga secara terus-menerusdan mempengaruhi semua kalangan masyarakat" (Suparmoko, 1998:209).

Rumus:

Rate of inflation of consumer price $=$

$$
\frac{\text { CPI (this year })- \text { CPI (last year })}{\text { CPI (last year })} \times 100 \%
$$

2. Gross Domestic Product (GDP) GDP adalah "jumlah produk berupa barang dan jasa yang dihasilkan oleh unit-unit produksi di suatu negara dalam satu tahun" (Rosyidi, 2011:105). Dalam penelitian ini, GDP yang digunakan atas dasar harga konstan yang diperoleh dari Bank Indonesiadan dihitung dalam satuan triliun rupiah per tiga bulan (triwulan) periode Januari 2011 sampai Desember 2015. Dilakukan uji geometric mean pada GDP untuk mendapatkan hasil rata-rata 
Syachfuddin, et al/Jurnal Ekonomi Syariah Teori dan Terapan Vol. 4 No. 12 Desember 2017: 977-993; PENGARUH FAKTOR MAKROEKONOMI, DANA PIHAK KETIGA DAN PANGSA PEMBIAYAAN TERHADAP PROFITABILITAS INDUSTRI PERBANKAN SYARIAH DI INDONESIA TAHUN 2011-2015

pertumbuhan GDP. Rumus geometric mean (Lind, dkk, 2010:70) sebagai berikut:

$G M=\sqrt[n]{\frac{\text { Value at end of period }}{\text { value at start of period }}}-1$

3. Pangsa Pasar

Pangsa pasar yang dimaksud disini adalah pangsa pembiayaan pada bank syariah. Pembiayaan yang ditawarkan bank syariah pun terdiri dari berbagai macam, misalnya mudharabah, murabahah, ijarah, dan lain-lain. Yang dimaksud dengan pangsa pembiayaan adalah "perbandingan antara jumlah pembiayaan yang disalurkan oleh bank syariah dengan jumlah kredit yang disalurkan perbankan nasional secara umum" (Hasan, 2010:57).

Data pangsa pembiayaan dinyatakan dalam persentase. Rumus yang digunakan untuk mencari pangsa pembiayaan adalah sebagai berikut (Stiawan, 2009:58):

Pangsa Pembiayaan =

$$
\begin{aligned}
& \text { Total Pembiayaan } \\
& \frac{\text { Bank Syariah }}{\text { Total Pembiayaan }} \\
& \text { Bank Nasional }
\end{aligned} \times 100 \%
$$

4. Dana Pihak Ketiga (DPK)

Dana pihak ketiga adalah "dana yang berasal dari masyarakat, baik perorangan maupun badan usaha, yang diperoleh bank dengan menggunakan berbagai instrumen produk simpanan yang dimiliki oleh bank (Kuncoro, 2002:155). Dalam penelitian ini,
DPK yang digunakan adalah data DPK setiap tiga bulan (triwulan) pada industri perbankan syariah Indonesia tahun 2011-2015. Data DPK dinyatakan dalam milyar rupiah.

5. Return on Asset (ROA)

$\mathrm{ROA}$ menggambarkan

"kemampuan bank dalam menghasilkan laba bersih melalui penggunaan sejumlah aktiva bank" (Husnan,1992:43). Menurut Surat Edaran BI No.3/30 DPNP tanggal 14 Desember 2001, ROA dapat dihitung dengan perbandingan antara laba sebelum pajak dan assets total (total aktiva). Formula return on asset (ROA) yang digunakan dalam Surat Edaran Bl tersebut di atas adalah :

$\mathrm{ROA}=\frac{\text { Laba sebelum pajak }}{\text { Total aset }} \times 100 \%$

\section{Prosedur Pengumpulan Data}

Prosedur pengumpulan data yang dilakukan peneliti adalah sebagai berikut:

1. Metode pengumpulan data tidak langsung

Dilakukan dengan mengumpulkan data penelitian yang bersumber dari data sekunder, yaitu:

a. Laporan keuangan yang dipublikasikan pada Statistik Perbankan Syariah di website Otoritas Jasa Kevangan (OJK).

b. Laporan perekonomian yang dipublikasikan pada Laporan 
Syachfuddin, et al/Jurnal Ekonomi Syariah Teori dan Terapan Vol. 4 No. 12 Desember 2017: 977-993; PENGARUH FAKTOR MAKROEKONOMI, DANA PIHAK KETIGA DAN PANGSA PEMBIAYAAN TERHADAP PROFITABILITAS INDUSTRI PERBANKAN SYARIAH DI INDONESIA TAHUN 2011-2015

Perekonomian Indonesia di website

Bank Indonesia (BI).

2. Studi kepustakaan

Dilakukan dengan mengumpulkan dan mempelajari berbagai jurnal, buku pustaka, artikel, dan bahanbahan lain yang digunakan untuk memahami permasalahan dan mendapatkan alternatif pemecahan masalah yang ada.

\section{Teknik Analisis Data}

Teknik analisis yang digunakan dalam penelitian ini adalah regresi linier berganda, proses perhitungannya dalam penelitian ini menggunakan program SPSS (Statistical Program for Social Science) versi 21.0. Tujuan dari analisis regresi berganda adalah menggunakan nilai-nilai variabel bebas yang diketahui untuk meramalkan nilai variabel tergantung.

Tahapan penelitian untuk menganalisa masalah yang telah dirumuskan adalah sebagai berikut:

1. Mengelompokkan rasio keuangan yang telah ada dalam laporan keuangan periode Maret 2011 hingga Desember 2015 pada industri perbankan syariah di Indonesia.

2. Mengelompokkandata makroekonomi yang telah ada dalam laporan perekonomian Indonesia per Maret 2011 hingga Desember 2015.

3. Melakukan pengujian statistik sebagai berikut:

a. Uji asumsi klasik yang terdiri atas uji normalitas, uji otokolerasi, Uji heteroskedastisitas, dan uji multikolinieritas.

b. Uji hipotesis yang terdiri atasuji $F$, uji $t$, dan uji determinasi kesesuaian atau $\cup j i R^{2}$.

\section{HASIL DAN PEMBAHASAN}

\section{Uji Multikolineritas}

Uji multikolinieritas dilakukan untuk menunjukkan ada atau tidaknya hubungan linier di antara variabel-variabel independen dalam model regresi. Pengujian ada atau tidaknya gejala multikolinieritas dapat dilakukan dengan mendeteksi nilai Variance Inflating Factor (VIF) dan tolerance-nya. Nilai VIF lebih dari 10 dan nilai tolerance kurang dari 0,10 menunjukkan terjadinya multikolinearitas yang berarti bahwa terdapat hubungan antara variabel independen dalam penelitian tersebut. Tabel 1 menunjukkan hasil uji multikolinieritas.

Tabel 1

Uji Multikolinieritas

\begin{tabular}{|l|c|c|l|l|}
\hline $\begin{array}{c}\text { Variabel } \\
\text { Bebas }\end{array}$ & $\begin{array}{c}\text { Nilai } \\
\text { Tolerance }\end{array}$ & $\begin{array}{c}\text { Nilai } \\
\text { VIF }\end{array}$ & $\begin{array}{l}\text { Interpretasi } \\
\text { Hasil }\end{array}$ & Keterangan \\
\hline Inflasi & .761 & 1.315 & $\begin{array}{l}\text { Nilai tolerance } \\
>0,10 \\
\text { Nilai VIF }<10\end{array}$ & $\begin{array}{l}\text { Tidak Terjadi } \\
\text { Multikolinieritas }\end{array}$ \\
\hline GDP & .823 & 1.216 & $\begin{array}{l}\text { Nilai tolerance } \\
>0,10 \\
\text { Nilai VIF }<10\end{array}$ & $\begin{array}{l}\text { Tidak Terjadi } \\
\text { Multikolinientas }\end{array}$ \\
\hline DPK & .310 & 3.224 & $\begin{array}{l}\text { Nilai tolerance } \\
<0,10 \\
\text { Nilai VIF }<10\end{array}$ & $\begin{array}{l}\text { Tidak Terjadi } \\
\text { Multikolinieritas }\end{array}$ \\
\hline Pangsa & .291 & 3.434 & $\begin{array}{l}\text { Nilai tolerance } \\
>0,10 \\
\text { Nilai VIF }<10\end{array}$ & $\begin{array}{l}\text { Tidak Terjadi } \\
\text { Multikolinientas }\end{array}$ \\
\hline
\end{tabular}

Sumber: Hasil pengolahan data

Tabel 1 menunjukkan hasil pengujian multikolinieritas. Tabel tersebut menunjukkan bahwa setiap variabel bebas memiliki nilai tolerance lebih besar 
Syachfuddin, et al/Jurnal Ekonomi Syariah Teori dan Terapan Vol. 4 No. 12 Desember 2017: 977-993; PENGARUH FAKTOR MAKROEKONOMI, DANA PIHAK KETIGA DAN PANGSA PEMBIAYAAN TERHADAP PROFITABILITAS INDUSTRI PERBANKAN SYARIAH DI INDONESIA TAHUN 2011-2015

dari 0,10 dan nilai VIF lebih kecil dari 10. Hasil uji multikolinieritas ini menunjukkan bahwa dalam model regresi yang digunakan pada penelitian ini tidak terdapat multikolinieritas, sehingga model regresi layak untuk digunakan.

\section{Uji Otokorelasi}

Uji otokorelasi bertujuan untuk melihat apakah dalam model regresi linear ada korelasi antara kesalahan pengganggu pada periode $t$ dengan kesalahan pengganggu pada periode $t_{-1}$ (sebelumnya). Salah satu cara yang dapat digunakan untuk mendeteksi ada atau tidaknya otokorelasi adalah dengan uji Durbin-Watson. Ketika nilai uji DurbinWatson berada berada diantara -2 sampai +2, maka variabel dapat dikatakan bebas dari masalah otokorelasi. Berikut adalah hasil uji otokorelasi:

Tabel 2

Uji Otokorelasi

Model Summary ${ }^{\circ}$

\begin{tabular}{|l|r|r|r|r|r|}
\hline Model & \multicolumn{1}{|c|}{$R$} & R Square & \multicolumn{1}{c|}{$\begin{array}{c}\text { Adjusted } R \\
\text { Square }\end{array}$} & $\begin{array}{c}\text { Std. Error of the } \\
\text { Estimate }\end{array}$ & Durbin-Watson \\
\hline 1 & $.919^{\mathrm{a}}$ & .844 & .802 & .40275 & 1.365 \\
\hline
\end{tabular}

Sumber: Hasil pengolahan data

Berdasarkan Tabe 2 diketahui nilai uji Durbin-Watson sebesar 1,365; nilai uji Durbin-Watson ini berada diantara -2 sampai +2. Berdasarkan hasil uji DurbinWatson tersebut, dapat ditarik kesimpulan bahwa tidak terdapat otokorelasi pada model regresi yang digunakan dalam penelitian ini.

\section{Uji Heteroskedastisitas}

Uji heteroskedastisitas menunjukkan bahwa varian variabel tidak sama untuk semua pengamatan.

heteroskedastisitas bertujuan untuk "menguji ketidaksamaan varian dari residual satu pengamatan ke pengamatan yang lain. Jika varian dari residual satu pengamatan ke pengamatan lain tetap, maka disebut homoskedastisitas. Model regresi yang baik adalah yang homoskedastisitas atau tidak terjadi heteroskedastisitas" (Ghozali, 2011:139).

Untuk menentukan ada atau tidaknya gejala heteroskedastisitas dapat menggunakan grafik scatterplot. Titik-titik yang terbentuk harus menyebar secara acak, tersebar baik di atas maupun dibawah angka nol pada sumbu Y. Bila kondisi ini terpenuhi maka di dalam model tidak terjadi heteroskedastisitas dan model regresi layak digunakan. Berikut merupakan hasil uji heteroskedastisitas:

Tabel 3

Uji Heteroskedastisitas Dependent Variable: ROA

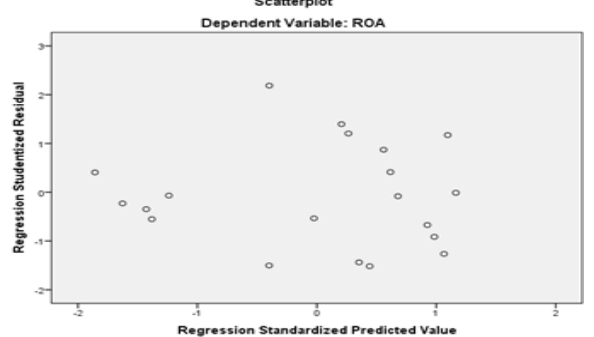

Sumber: Hasil pengolahan data

Dengan melihat grafik scatterplot di atas, terlihat titik-titiknya menyebar secara acak dan tidak membentuk pola yang jelas serta tersebar baik di atas maupun di bawah angka nol pada sumbu Y. Maka dapat disimpulkan bahwa tidak terjadi gejala heteroskedastisitas.

\section{Uji Normalitas}


Syachfuddin, et al/Jurnal Ekonomi Syariah Teori dan Terapan Vol. 4 No. 12 Desember 2017: 977-993; PENGARUH FAKTOR MAKROEKONOMI, DANA PIHAK KETIGA DAN PANGSA PEMBIAYAAN TERHADAP PROFITABILITAS INDUSTRI PERBANKAN SYARIAH DI INDONESIA TAHUN 2011-2015

Uji normalitas bertujuan untuk mengetahui apakah masing-masing variabel berdistribusi normal atau tidak. Salah satu cara untuk menguji normalitas data yaitu dengan metode grafik (Normal o-Plot). Deteksi asumsi model ini dapat dilihat dari penyebaran data (titik) pada sumbu diagonal grafik. Jika data menyebar di sekitar garis diagonal mengikuti arah garis tersebut atau pola histogramnya, maka hal itu menunjukkan pola berdistribusi normal dan dengan begitu model regresi memenuhi asumsi normalitas. Berikut adalah hasil uji normalitas:

\section{Tabel 4}

\section{Uji Normalitas}

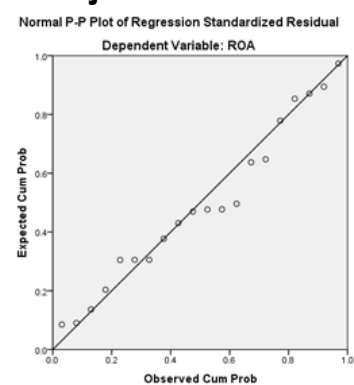

Sumber: Hasil pengolahan data

Output grafik Normal p-Plot menunjukkan bahwa data (titik) menyebar di sekitar garis diagonal dan mengikuti arah garis diagonal. Selanjutnya, hal tersebut menunjukkan pola distribusi normal sehingga model regresi memenuhi asumsi normalitas.

\section{Uji Koefisien Determinasi $\left(R^{2}\right)$}

Koefisien Determinasi $\left(R^{2}\right)$ digunakan untuk mengukur seberapa jauh kemampuan variabel independen dalam menjelaskan variabel dependen. Nilai koefisien determinasi adalah antara nol dan satu. Apabila koefisien determinasi
$\left(R^{2}\right)$ bernilai nol, maka variabel bebas sama sekali tidak berpengaruh terhadap variabel terikat. Dan apabila koefisien determinasi semakin mendekati satu, maka dapat dikatakan bahwa variabel bebas berpengaruh terhadap variabel terikat Hasil koefisien determinasi $\left(R^{2}\right)$ dalam penelitian ini dapat dilihat pada Tabel 5 berikut:

Tabel 5

Uji Koefisien Determinasi $\left(R^{2}\right)$

\begin{tabular}{|l|r|r|r|r|r|}
\hline Model & \multicolumn{1}{|c|}{ Model Summary $^{\circ}$} & R Square & $\begin{array}{c}\text { Adjusted R } \\
\text { Square }\end{array}$ & $\begin{array}{c}\text { Std. Error of the } \\
\text { Estimate }\end{array}$ & Durbin-Watson \\
\hline 1 & $.919^{\mathrm{a}}$ & .844 & .802 & .40275 & 1.365 \\
\hline
\end{tabular}

sebesar $84,4 \%$ artinya bahwa variabel inflasi, gross domestic product (GDP), dana pihak ketiga (DPK), dan pangsa pasar dapat menjelaskan variabel return on asset (ROA) sebesar $84,4 \%$. Sedangkan $15,6 \%$ lainnya dipengaruhi oleh faktorfaktor lain di luar variabel yang tidak diteliti.

\section{Analisis Regresi Linier Berganda}

Analisis regresi linier berganda digunakan untuk mengetahui pengaruh beberapa variabel independen terhadap satu variabel dependen. Analisis regresi linear berganda dalam penelitian ini digunakan untuk mengetahui pengaruh inflasi, gross domestic product (GDP), dana pihak ketiga (DPK), dan pangsa pasar terhadap return on asset (ROA) pada industri perbankan syariah di Indonesia. Berikut adalah hasil analisis regresi linier berganda: 
Tabel 6

Analisis Regresi Linier Berganda

\begin{tabular}{|l|c|c}
\hline \multicolumn{1}{|c|}{ Variabel } & Koefisien Regresi & Keterangan \\
\hline Konstanta & 110.126 & Intersep \\
\hline Inflasi & -.031 & Bemilai negatif \\
\hline GDP & -.051 & Bemilai negatif \\
\hline DPK & -4.409 & Bemilai negatif \\
\hline Pangsa Pasar & 2.782 & Bemilai positif \\
\hline
\end{tabular}

Sumber: Hasil pengolahan data

Berdasarkan hasil uji pada Tabel 6,

maka persamaan regresi linier bergandanya adalah sebagai berikut:

$\mathrm{R} 0 \mathrm{~A}=110,126-0,031(\mathrm{INF})-0,051(\mathrm{GDP})-4,409(\mathrm{DPK})+2,782(\mathrm{PP})$

Uji $F$

Uji $F$ dilakukan untuk mengetahui apakah semua variabel bebas secara bersama-sama (simultan) berpengaruh terhadap variabel terikat, yaitu dengan membandingkan $F_{\text {tabel }}$ dan Fhitung. Dalam penelitian ini terdapat dua hipotesis pada uji $F$, yaitu:

$\mathrm{H}_{0}$ : Secara simultan inflasi, gross domestic product (GDP), dana pihak ketiga (DPK), dan pangsa pasar tidak memiliki pengaruh yang signifikan terhadap return on asset (ROA)

$\mathrm{H}_{1}$ : Secara simultan simultan inflasi, gross domestic product (GDP), dana pihak ketiga (DPK), dan pangsa pasar memiliki pengaruh yang signifikan terhadap return on asset (ROA)

Hasil perhitungan uji $F$ dilakukan dengan menggunakan program SPSS 21 yang dapat dilihat pada Tabel 7 berikut:
Tabel 7

Hasil Uji Hipotesis (Uji $F$ )

\begin{tabular}{|c|c|c|c|c|}
\hline $\mathrm{F}_{\text {bitug }}$ & $\mathrm{F}_{\text {tabel }}$ & Signifikansi & Interpretasi & Keterangan \\
\hline 20,293 & 3,06 & 0,000 & $\mathrm{~F}_{\text {hitumg }}>\mathrm{F}_{\text {Tabel }}=\mathrm{H}_{0}$ ditolak & $\mathrm{H}_{0}$ ditolak sehingga \\
& & & $(20,293>3,06)$ & variabel independen \\
& & & Signifikansi $<0,05=$ & secara simultan \\
& & & $\mathrm{H}_{0}$ ditolak & berpengaruh \\
& & & $(0,000<0,05)$ & $\begin{array}{c}\text { signifikan terhadap } \\
\text { variabel dependen }\end{array}$ \\
& & & & \\
\hline
\end{tabular}

Sumber: Hasil pengolahan data

Hasil uji $F$ di atas menunjukkan nilai Fhitung lebih besar dibandingkan Ftabel dan signifikansi lebih kecil dibandingkan tingkat a maka $\mathrm{H}_{0}$ ditolak dan dapat disimpulkan bahwa secara bersama-sama (simultan) variabel inflasi, gross domestic product (GDP), dana pihak ketiga (DPK), dan pangsa pasar berpengaruh signifikan terhadap return on asset (ROA).

Uji $\boldsymbol{t}$

Uji † digunakan untuk mengetahui pengaruh variabel independen terhadap variabel dependen secara parsial, yaitu dengan melihat nilai signifikansi dan membandingkan antara tabel dan thitung. Apabila nilai signifikansi lebih kecil dari 0,05 dan thitung $<t_{\text {tabel }}$ atau thitung $>t_{\text {tabel }}$ maka dapat disimpulkan bahwa variabel independen memiliki pengaruh signifikan secara parsial terhadap variabel dependen. Dalam penelitian ini terdapat dua hipotesis pada uji $t$, yaitu:

$\mathrm{H}_{0}$ : Secara parsial inflasi, gross domestic product (GDP), dana pihak ketiga (DPK), dan pangsa pasar tidak memiliki pengaruh yang signifikan terhadap return on asset (ROA) 
Syachfuddin, et al/Jurnal Ekonomi Syariah Teori dan Terapan Vol. 4 No. 12 Desember 2017: 977-993; PENGARUH FAKTOR MAKROEKONOMI, DANA PIHAK KETIGA DAN PANGSA PEMBIAYAAN TERHADAP PROFITABILITAS INDUSTRI PERBANKAN SYARIAH DI INDONESIA TAHUN 2011-2015

$\mathrm{H}_{1}$ : Secara parsial inflasi, gross domestic product (GDP), dana pihak ketiga (DPK), dan pangsa pasar memiliki pengaruh yang signifikan terhadap return on asset (ROA)

Hasil perhitungan uji $\uparrow$ dilakukan dengan menggunakan program SPSS 21 yang dapat dilihat pada Tabel 8 berikut:

Tabel 8

Hasil Uji Hipotesis (Uji $t$ )

\begin{tabular}{l|c|c|r|c}
\hline Variabel Independen & $\mathrm{t}_{\text {bitug }}$ & $\mathrm{t}_{\text {tabel }}$ & Signifikansi & Keterangan \\
\hline Inflasi & $-0,472$ & 1,75305 & 0,644 & $\mathrm{H}_{0}$ diterima \\
\hline GDP & $-0,274$ & $-1,75305$ & 0,788 & $\mathrm{H}_{0}$ diterima \\
\hline DPK & $-8,671$ & $-1,75305$ & 0,000 & $\mathrm{H}_{0}$ ditolak \\
\hline Pangsa Pasar & 6,157 & $-1,75305$ & 0,000 & $\mathrm{H}_{0}$ ditolak \\
\hline
\end{tabular}

Sumber: Hasil pengolahan data

Berdasarkan hasil uji hipotesis di atas dapat disimpulkan bahwa secara parsial variabel inflasi dan GDP tidak berpengaruh signifikan terhadap ROA sedangkan variabel DPK dan pangsa pasar secara pasrsial berpengaruh signifikan terhadap ROA.

Pembahsan Pengaruh Inflasi, GDP, DPK, dan Pangsa Pasar terhadap ROA Industri Perbankan Syariah di Indonesia

1. Hasil penelitian menunjukkan bahwa inflasi tidak memiliki pengaruh signifikan terhadap ROA. Hal tersebut ditunjukkan oleh nilai signifikansi sebesar 0,644 dimana nilai signifikansinya lebih besar dari 0,05 sehingga $\mathrm{H}_{0}$ diterima. Nilai uji ${ }^{\dagger}$ variabel inflasi sebesar $-0,472$ sehingga dalam penelitian ini didapati bahwa inflasi tidak berpengaruh signifikan dan bernilai negatif.

2. Hasil penelitian menunjukkan bahwa GDP tidak memiliki pengaruh signifikan terhadap ROA. Hal tersebut ditunjukkan
Oleh nilai signifikansi sebesar 0,788 yang lebih besar dari 0,05 sehingga $\mathrm{H}_{0}$ diterima. Nilai uji $t$ variabel GDP sebesar $-0,274$ sehingga dalam penelitian ini ternyata bahwa GDP tidak berpengaruh signifikan dan bernilai negatif.

3. Hasil penelitian menunjukkan bahwa DPK memiliki pengaruh signifikan terhadap ROA. Hal tersebut ditunjukkan oleh nilai signifikansi sebesar 0,000 dan ini berarti bahwa nilai signifikansinya lebih besar dari 0,05 sehingga $\mathrm{H}_{0}$ ditolak. Nilai uji $t$ variabel DPK sebesar 8,671 menunjukkan bahwa DPK berpengaruh signifikan dan bernilai negatif.

4. Hasil penelitian menunjukkan bahwa pangsa pasar memliki pengaruh signifikan terhadap ROA. Hal tersebut ditunjukkan oleh nilai signifikansi sebesar 0,000 yang menunjukkan bahwa signifikansinya lebih besar dari 0,05 sehingga $\mathrm{H}_{0}$ ditolak. Nilai uji $t$ variabel inflasi sebesar 6,157 sehingga dalam penelitian ini berpengaruh signifikan dan bernilai positif.

5. Hasil penelitian tentang pengaruh inflasi, GDP, DPK, dan pangsa pasar terhadap ROA secara simultan menunjukkan nilai signifikansi pada uji $F$ yaitu lebih kecil dari a $(0,000<0,05)$. Berdasarkan hasil uji $F$ tersebut dapat disimpulkan bahwa $\mathrm{H}_{0}$ ditolak sehingga dapat disimpulkan bahwa inflasi, GDP, DPK, dan pangsa pasar secara simultan berpengaruh signifikan terhadap ROA.

\section{SIMPULAN}


Syachfuddin, et al/Jurnal Ekonomi Syariah Teori dan Terapan Vol. 4 No. 12 Desember 2017: 977-993; PENGARUH FAKTOR MAKROEKONOMI, DANA PIHAK KETIGA DAN PANGSA PEMBIAYAAN TERHADAP PROFITABILITAS INDUSTRI PERBANKAN SYARIAH DI INDONESIA TAHUN 2011-2015

1. Hasil dari uji $F$ pada model regresi adalah variabel inflasi, GDP, DPK, dan pangsa pasar secara simultan berpengaruh signifikan terhadap ROA industri perbankan syariah di Indonesia.

2. Hasil uji parsial pada model regresi adalah variabel inflasi dan GDP tidak berpengaruh signifikan terhadap ROA sedangkan variabel DPK dan pangsa pasar berpengaruh signifikan terhadap ROA.

\section{DAFTAR PUSTAKA}

Anshori, Muslich dan Sri Iswati. 2009. Buku Ajar Metodologi Penelitian Kuantitatif. Surabaya: Pusat Penerbitan dan Percetakan Unair (AUP)

Antonio, Muhammad Syafi'i. 2001. Bank Syariah dari Teori ke Praktik. Jakarta: Gema Insan Press

Arifin, Zainul. 2009. Dasar-dasar Manajemen Bank Syariah. Jakarta: Raja Grafindo Persada

Ariyanto, Taufik. 2005. Profil Persaingan Usaha dalam Industri Perbankan Indonesia, Perbanas Finance and Banking Journal, Vol.6, No.2, Desember 2004; 95-108. (online). (http://perbanasinstitute.ac.id, diakses 7 Juni 2016)

Bank Indonesia. 2009. Peraturan Bank Indonesia Nomor 11/23/PBI/2009 Tanggal 1 Juni 2009 Tentang Bank Pembiayaan Rakyat Syariah. (online). (http://www.bi.go.id, diakses 10 Juni 2016)
2004. Surat Edaran Nomor 3/30/DPNP 2001 Perihal Laporan Kevangan Publikasi Triwulanan dan Bulanan Bank Umum serta Laporan Tertentu yang Disampaikan kepada Bank Indonesia. (online). (http://www.bi.go.id, diakses 26 Juni 2016)

Boediono. 1982. Ekonomi Makro. Yogyakarta: BPFE Yogyakarta

Gale, B.T. 1972. Market Share and Rate of Return. The Review of Economics and Statistics, Vol.54, No.4, November1972; 412-423. (online). (http://www.jstor.org, diakses 13 Juni 2016)

Ghozali, Imam. 2011. Aplikasi Analisis Multivariate dengan Program IBM SPSS 19, Edisi Kelima. Semarang: Universitas Diponegoro

Hasibuan, Malayu S.P. 2001. Dasar-dasar Perbankan. Jakarta: Bumi Aksara

Hasan, M.labal. 2001. Pokok-pokok Materi Statistik 1 (Statistik Deskriptif), Edisi Kedua. Jakarta: Bumi Aksara

Hasan, Ali. 2010. Marketing Bank Syariah : Cara Jitu Meningkatkan Pertumbuhan Pasar Bank Syariah. Jakarta : Ghalia Indonesia

Husnan, Suad. 1992. Manajemen Keuangan. Yogyakarta: BPFE Yogyakarta

Jones, Charles P. 1992. Introduction to Financial Management. USA: Richard D. Irwin Inc

Karim, Adiwarman A. 2010. Bank Islam: Analisis Figh dan Keuangan, Edisi Keempat. Jakarta: Raja Grafindo Persada 
Syachfuddin, et al/Jurnal Ekonomi Syariah Teori dan Terapan Vol. 4 No. 12 Desember 2017: 977-993; PENGARUH FAKTOR MAKROEKONOMI, DANA PIHAK KETIGA DAN PANGSA PEMBIAYAAN TERHADAP PROFITABILITAS INDUSTRI PERBANKAN SYARIAH DI INDONESIA TAHUN 2011-2015

Kottler, Philip. 2006. Marketing Management. New Jersey: Pearson Prentice Hall

Kuncoro, Mudrajad dan Suhardjono. 2002. Manajemen Perbankan Teori dan Aplikasi. Yogyakarta: BPFE Yogyakarta Lind, Douglas A, dkk. 2010. Statistical Techniques in Business and Economics, 14 $4^{\text {th }}$ Edition. New York: Mc Graw-Hill Mankiw, N Gregory. 2002. Principles of Economics, $14^{\text {th }}$ Edition. Australia: Thomson

Republik Indonesia. 2008. Undang-Undang Nomor 21 Tahun 2008 Tentang Perbankan Syariah. Jakarta: Republik Indonesia

Rosyidi, Suherman. 2011. Pengantar Teori Ekonomi: Pendekatan kepada Teori Ekonomi Mikro dan Makro. Jakarta: Raja Grafindo Persada

Sahara, Ayu Yanita. 2013. Analisis Pengaruh Inflasi, Suku Bunga Bl, dan Produk Domestik Bruto terhadap Return on Asset (ROA) Bank Syariah di Indonesia. Jurnal IImu Manajemen, Vol.1, No.1, Januari. Universitas Negeri Surabaya. (online). (http://ejournal.unesa.ac.id, diakses 22 Agustus 2016)

Samuelson, Paul A. dan William D. Nordhaus. 1992. Economics, 14th Edition. New York: Mc Graw-Hill

Stanton, William J. 1978. Fundamentals of Marketing. Tokyo: Mc Graw-Hill

Stiawan, Adi. 2009. Analisis Pengaruh Faktor Makroekonomi, Pangsa Pasar, dan Karakteristik Bank terhadap Profitabilitas Bank Syariah (Studi pada
Bank Syariah Periode 2005-2008). Thesis diterbitkan. Semarang: Universitas Diponegoro

Sugiyono. 2012. Memahami Penelitian Kuantitatif dan Kualitatif dan R\&B. Bandung: Alfabeta

Sukirno. 2006. Ekonomi Pembangunan: Proses, Masalah, dan Dasar Kebijakan. Jakarta: Kencana

Suparmoko. 1998. Pengantar Ekonomika Makro, Edisi Keempat. Yogyakarta: BPFE Yogyakarta 